\title{
Study of the Process of the Black Sea Upper Layer Mixing in the Zone of the Rim Current Activity in Winter Based on the Drifters Data
}

\author{
A. A. Sizov*, T. M. Bayankina, A. V. Yurovsky \\ Marine Hydrophysical Institute of RAS, Sevastopol, Russian Federation \\ *sizov_anatoliy@mail.ru
}

\begin{abstract}
Purpose. The process of the upper layer mixing in the western Black Sea during the heightened heat flux from its surface in the winter season is studied. The mechanism forming average temperature both in the upper mixed layer and in the layer below the lower boundary in the seasonal thermocline is analyzed.

Methods and Results. Measurements of the thermistor chain drifters as well as the MERRA reanalysis data and the simulation results of the regional model RegCM4 which included the ERA-Interim reanalysis (2012-2014) data as the input information, were involved in the calculations. It is revealed that growth of the wind speed and the total heat flux from the sea surface was accompanied by increase of the current velocity that resulted in intensification of turbulent mixing in the upper layer (40-50 m depth) and lowering of its average temperature. It is also found out that increase of the current velocity was followed by deepening of the seasonal thermocline and cold intermediate layer; whereas its decrease contributed to elevation of cold waters from the lower boundary of the upper mixed layer to the smaller depths. At the same time, diminution of the cold intermediate layer depth was observed. At lowering of the current velocity, this resulted in decrease of the upper mixed layer average temperature, and growth of the temperature in the layer below the seasonal thermocline.

Conclusions. The current velocity intensification induces deepening of the seasonal thermocline and the cold intermediate layer; whereas its decrease promotes elevation of these layers to smaller depths. This process results in lowering of the upper mixed layer average temperature.
\end{abstract}

Keywords: Rim Current, upper mixed layer, cold intermediate layer, seasonal thermocline, atmospheric forcing.

Acknowledgements: The investigation is carried out within the framework of the state task on theme No. 0827-2018-0001 "Fundamental studies of interaction processes in the ocean-atmosphere system conditioning regional spatial-temporal variability of natural environment and climate". The authors are grateful to Dr. Sci. (Phys.-Math.), Professor V.V. Efimov for discussing the data and the obtained results as well as to the reviewer for his helpful remarks.

For citation: Sizov, A.A., Bayankina, T.M. and Yurovsky, A.V., 2019. Study of the Process of the Black Sea Upper Layer Mixing in the Zone of the Rim Current Activity in Winter Based on the Drifters Data. Physical Oceanography, [e-journal] 26(3), pp. 260-270. doi:10.22449/1573-160X-2019-3-260-270

DOI: 10.22449/1573-160X-2019-3-260-270

(C) 2019, A. A. Sizov, T. M. Bayankina, A. V. Yurovsky

(C) 2019, Physical Oceanography

Introduction

The upper mixed sea layer is intensively formed in the winter season, when the processes of turbulent exchange and convection are activated. The temperature of the upper layer is formed under effect of current velocity shift and convection ${ }^{1,2}$. Wind mixing and convection depend on the atmospheric circulation conditions, which noticeably changes both on the interannual and interdecadal scale [1-5]. The variability of thermal and dynamic processes in the near-water atmosphere of the Black Sea creates appropriate conditions for heat flux from its surface, which leads to interannual fluctuations in the upper layer heat content $[5,6]$.

\footnotetext{
${ }^{1}$ Bulgakov, N.P., 1975. Convection in the Ocean. Moscow: Nauka, 272 p.

2 Dobrovolsky, A.D., Ed., 1977. Convective Mixing in the Sea. Moscow: University Press, 239 p.
} 
The mixing processes in this layer are related to the Rim Current dynamics, the intensification and weakening of which are reliably reconstructed according to satellite altimetry data [7-9]. In recent years, drifting buoys with a thermistor chain (drifters) have become widely used for studying thermal processes in the sea upper layer [10]. Measurement data from the drifters allow investigating the processes of formation of the sea upper layer thermal state and exchange mechanisms in the Rim Current area.

The purpose of this work is to study the process of the Black Sea western part upper layer winter mixing in the Rim Current area according to the data of drifters.

\section{Data and research technique}

The analysis of the sea upper layer mixing process, including the upper mixed layer (UML) and the cold intermediate layer (CIL), was carried out according to the data obtained by drifters with a $\left(S V P \_B T C 80\right)$ [10]. The initial data of drifters on the temperature in $0.2-80 \mathrm{~m}$ layer was taken from the oceanographic database of Marine Hydrophysical Institute (MHI). Considering the purpose of the work, the cases when SVP_BTC80 type drifters carried out measurements in the western part of the sea under conditions of variable heat flux from the surface at wind velocities of varying intensity were selected. One drifter (No. 249940) was located in the Rim Current northern branch and carried out measurements from December 14-31, 2012 under conditions of a relatively weak cold invasion. These conditions were provided by the cold front of the cyclone entering the Black Sea western part. The second drifter (No. 248990) was located in the Rim Current southern branch on January 26 - February 10, 2014 and worked under conditions of a strong cold invasion of Arctic air masses (Arctic invasion) into the northern part of the sea. Thermistor chains of the drifters provided the upper layer temperature measurements every $5 \mathrm{~m}$. The variability of drift $V$ and geostrophic $V_{g}$ velocity components of the Rim Current was estimated using the data on the surface wind and satellite altimetry data [11-13].

The estimation of the surface wind velocity and the flux of sensible and latent heat from the sea surface $(H+L E), \mathrm{W} \cdot \mathrm{m}^{-2}$, was performed according to MERRA reanalysis array (https://disc.gsfc.nasa.gov/datasets?page=1) and regional reanalysis according to $\operatorname{RegCM4}$ model [14]. Cold invasion was determined by the air temperature and wind velocity from the data of these reanalyses. The sea surface temperature was selected from NOAA ESRL reanalysis array (http://www.esrl.noaa.gov/psd), the geostrophic velocity and surface current velocity in the Rim Current action zone - from the data array posted on the MHI marine portal (https://mhi-ras.ru).

\section{The obtained results}

The drifters' position scheme is shown in Fig. 1. It can be seen that their trajectories in the northern and southern Rim Current branches are not related to their capture by synoptic eddies. The analyzed drifters were captured by the Rim Current flow, and this largely determined the variability structure of the UML temperature field and the dynamics of seasonal thermocline and CIL. For the analysis, the measurement 
data obtained at wind velocity over $10 \mathrm{~m} \cdot \mathrm{s}^{-1}$ and a negative air temperature (cold invasion conditions) were selected. The cold invasion in the rear of the cyclone on December 17-21, 2012 with $-3.4{ }^{\circ} \mathrm{C}$ average air temperature and $10.6 \mathrm{~m} \cdot \mathrm{s}^{-1}$ wind velocity, as well as an Arctic invasion from January 29 to February 3, 2014 with $9.3^{\circ} \mathrm{C}$ average air temperature and $11.2 \mathrm{~m} \cdot \mathrm{s}^{-1}$ wind velocity were selected.

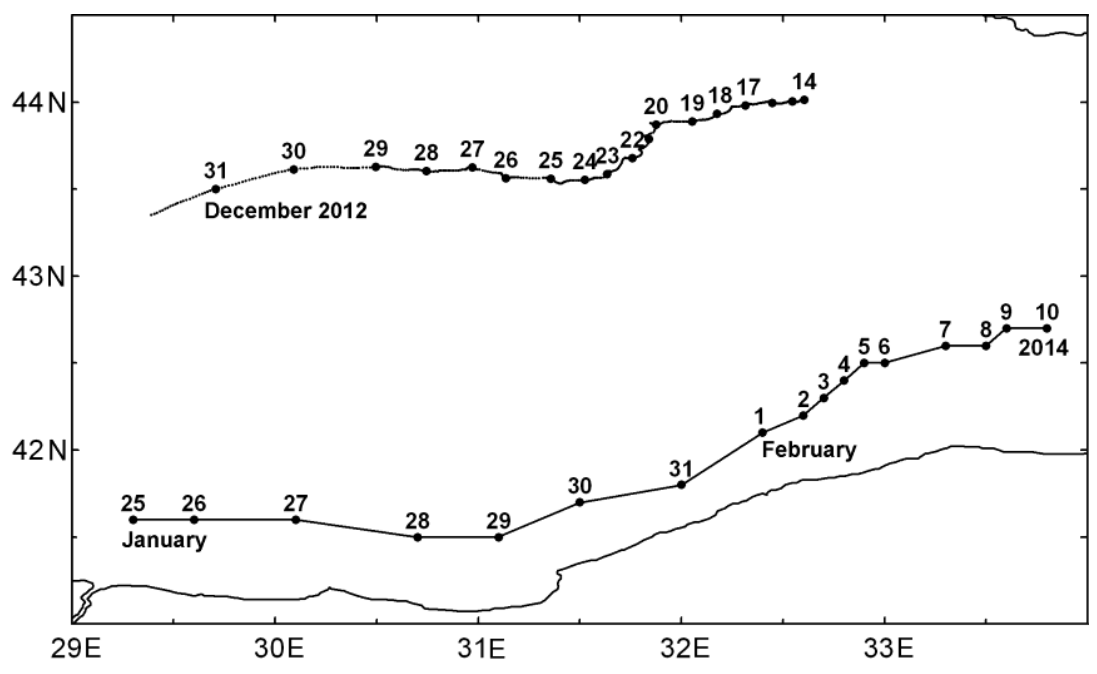

F i g. 1. Scheme of the drifters' movement in the northern (2012) and southern (2014) branches of the Rim Current

We consider the upper sea layer temperature variability in the zone of action of the northern and southern Rim Current branches (Fig. 2). The position of the isotherms in the northern branch during the cold invasion on December 17-21, 2012 (Fig. 2, a) indicates a noticeable decrease in the UML temperature, for the lower boundary of which $9{ }^{\circ} \mathrm{C}$ isotherm was taken. According to MERRA reanalysis, the difference between the water and air temperature $\Delta T=T_{\mathrm{w}}-T_{\mathrm{a}}$ at the point of drifter location was maximum (more than $4{ }^{\circ} \mathrm{C}$ ) on December $21-23$. At the same time, the maximum wind velocity $\left(8-12 \mathrm{~m} \cdot \mathrm{s}^{-1}\right)$ was observed on December 18-20. It was on December 19 and 20 when the cyclone cold front with the northeastern wind passed through the region of the drifter localization. It provided the maximum heat flux from the sea surface (Table 1). This led to the fact that the UML temperature decreased on December $17-19$ by $0.13{ }^{\circ} \mathrm{C}$ per day as a result of mixing. A similar decrease in the UML temperature was observed in the Rim Current southern branch. In this case, $8.5^{\circ} \mathrm{C}$ isotherm was taken as the lower UML boundary. Here, the maximum $\Delta T\left(2.6-4.5^{\circ} \mathrm{C}\right)$ values were observed on January 30 - February 1, 2014, and the maximum wind velocities $\left(9-10 \mathrm{~m} \cdot \mathrm{s}^{-1}\right.$ ) were recorded on February 2 and 3. Therefore, the maximum heat flux from the sea surface was observed on January 30 - February 3 (Table 1), as a result of which the average UML temperature decreased by $0.07^{\circ} \mathrm{C}$ per day. 


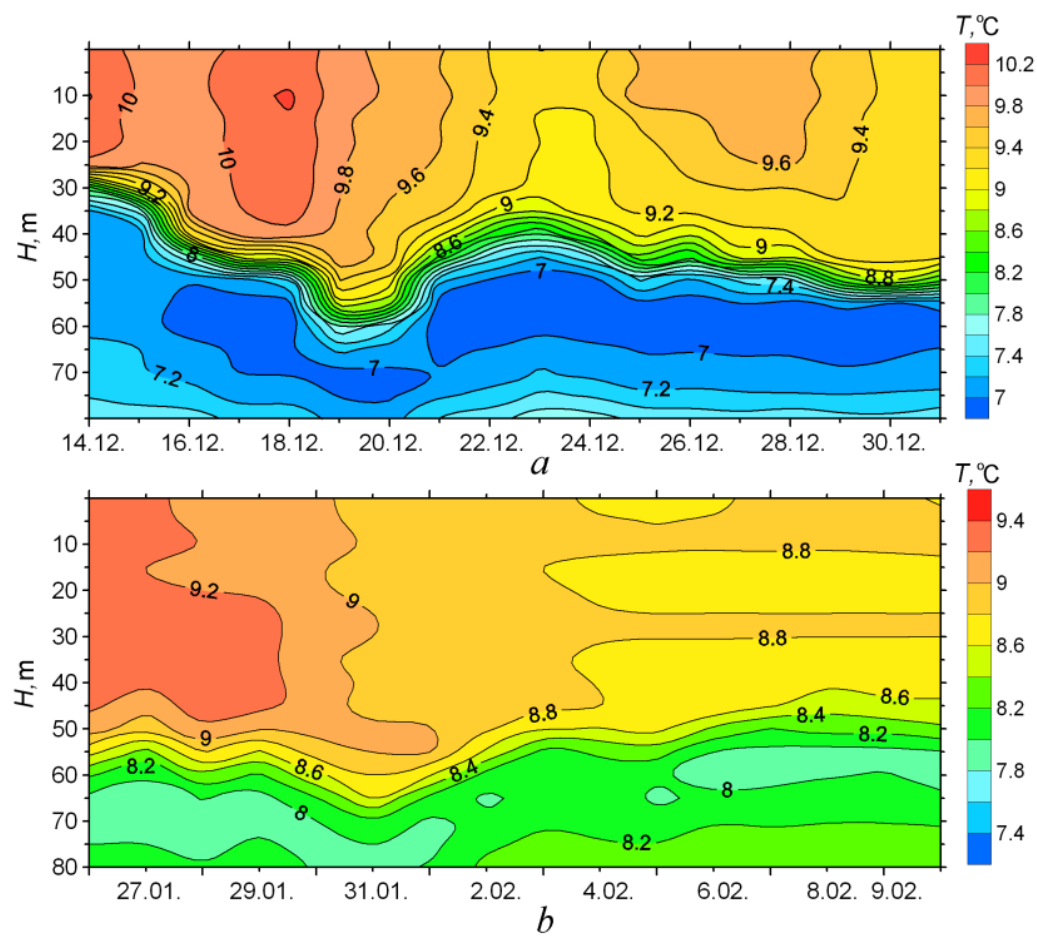

F i g. 2. Temporal temperature variability of the sea upper layer in the northern $(a)$ and southern $(b)$ branches of the Rim Current in 2012 and 2014, respectively

In Table 1 the values of total heat flux during cold invasions, at which a significant decrease in the sea upper layer average temperature took place, are underlined.

As can be clearly seen in Fig. 2, $a$, the drifter, moving in the Rim Current, recorded a noticeable variation in the UML temperature: on December 18-24, 2012, it decreased (Table 1). However, the total heat flux from the sea surface, providing the sea surface cooling, increased only on December 17-19, and then decreased until December 28. As follows from the Table. 1, the UML average temperature continued to decrease until December 24, after which it began to grow. The decrease in the UML temperature on December 17-19 (Fig. 2, a) made up, on average, $0.13{ }^{\circ} \mathrm{C}$ per day (Table 1). Such a significant decrease in the upper 40-meter layer temperature was due to the heat flux from the sea surface that increased by $30 \mathrm{~W} \cdot \mathrm{m}^{-2}$ per day.

We consider the processes observed in the UML in the Rim Current southern branch region (Fig. 2, b, Table 1). It can be seen that the temperature of the water masses is more uniform. Apparently, this is due to the fact that in 2014 the drifter carried up measurements in the middle of winter, when the sea upper layer was well mixed. But even in this case, as in December 2012, the features in the position of isotherms related to the CIL mixing with increasing wind velocity and total heat flux from the sea surface are well distinguished. A sharp decrease in the UML average temperature was also observed here (Table 1). 


\section{Variability of the upper mixed layer (UML) average temperature depending on the total heat flow $(H+L E)$}

\begin{tabular}{cccc|c|c|c}
\hline Date & $\begin{array}{c}(H+L E), \mathrm{W} \cdot \mathrm{m}^{-2} \\
\text { (in drifter point) }\end{array}$ & $\begin{array}{c}\mathrm{T}_{\mathrm{av}},{ }^{\circ} \mathrm{C} \\
(\mathrm{UML})\end{array}$ & Date & $\begin{array}{c}(H+L E), \mathrm{W} \cdot \mathrm{m}^{-2} \\
\text { (in drifter point) }\end{array}$ & $\begin{array}{c}\mathrm{T}_{\mathrm{av}},{ }^{\circ} \mathrm{C} \\
(\mathrm{UML})\end{array}$ \\
\hline \multicolumn{2}{c}{ Northern branch of the Rim Current } & \multicolumn{2}{c}{ Southern } & branch of the Rim Current \\
\hline 14.12 .2012 & 120 & 10.18 & 26.01 .2014 & 50 & 9.25 \\
15.12 .2012 & 130 & 9.92 & 27.01 .2014 & 75 & 9.26 \\
16.12 .2012 & 170 & 9.84 & 28.01 .2014 & 50 & 9.24 \\
17.12 .2012 & $\underline{140}$ & 10.06 & 29.01 .2014 & $\underline{50}$ & 9.20 \\
18.12 .2012 & $\underline{180}$ & 10.16 & 30.01 .2014 & $\underline{100}$ & 9.07 \\
19.12 .2012 & $\underline{200}$ & 9.79 & 31.01 .2014 & $\underline{100}$ & 8.94 \\
20.12 .2012 & 180 & 9.65 & 01.02 .2014 & $\underline{100}$ & 8.90 \\
21.12 .2012 & 140 & 9.58 & 02.02 .2014 & $\underline{120}$ & 8.86 \\
22.12 .2012 & 110 & 9.36 & 03.02 .2014 & 120 & 8.85 \\
23.12 .2012 & 130 & 9.18 & 04.02 .2014 & 70 & 8.79 \\
24.12 .2012 & 80 & 9.12 & 05.02 .2014 & 70 & 8.78 \\
25.12 .2012 & 58 & 9.46 & 06.02 .2014 & 50 & 8.78 \\
26.12 .2012 & 20 & 9.49 & 07.02 .2014 & 35 & 8.79 \\
27.12 .2012 & 25 & 9.51 & 08.02 .2014 & 20 & 8.77 \\
28.12 .2012 & 20 & 9.56 & 09.02 .2014 & 10 & 8.79 \\
- & - & - & 10.02 .2014 & 0 & 8.79 \\
\hline
\end{tabular}

One of the features in changing the position of isotherms, by which the upper seasonal thermocline boundary was determined: $9.0{ }^{\circ} \mathrm{C}$ (December 2012) and $8.5^{\circ} \mathrm{C}$ (January - February 2014), is their deepening during the increased values of total heat flux from the sea surface and wind velocity (atmospheric forcing), as well as the rise to shallower depths during the atmospheric forcing decrease (Fig. 2, Table 1). The characteristic bending of $9.2{ }^{\circ} \mathrm{C}$ (December 23-24) and $8.8{ }^{\circ} \mathrm{C}$ (February 3-4) isotherms indicates their rise to lower depths. This process can be represented as a manifestation of the oscillatory motion of "seasonal thermocline CIL" system, which is removed from the equilibrium state by atmospheric forcing.

In the considered cases the movement velocity of drifters was regulated by the Rim Current velocity. As shown in Fig. 1, $b$, the drifter in the southern branch moved in the zonal direction. At the same time, with the atmospheric forcing intensification (January 29 - February 3), the drifter velocity noticeably changed: from January 29 to February 1 it was, on average, $0.5 \mathrm{~m} \cdot \mathrm{s}^{-1}$, on February $1-3$ it decreased to $0.15 \mathrm{~m} \cdot \mathrm{s}^{-1}$ and remained so until February 6 . Wind velocity for this sea area, taken from MERRA reanalysis, remained high $\left(8-10 \mathrm{~m} \cdot \mathrm{s}^{-1}\right)$ from 264 
January 29 to February 3, but the direction noticeably changed: on January 29-31 it coincided with the one of Rim Current, and on February 1-3 it changed to the eastern one. These local changes in the wind direction can be an explanation for the Rim Current and the drifter velocity variations. But, as shown in Fig. 2, $b$, simultaneously with the change in the Rim Current velocity, the depth of the seasonal thermocline upper boundary also changed. Now we are to consider this process in more detail.

In the Rim Current northern branch, where the seasonal thermocline upper boundary was located at about $40 \mathrm{~m}$ depth, the variation of thermocline and CIL location depths significantly depended on the fluctuations of the surface current. The comparison of average velocity values for December 16-28, 2012 showed that the surface current velocity $\left(V=0.26 \mathrm{~m} \cdot \mathrm{s}^{-1}\right)$ was about two times higher than the geostrophic one $\left(V_{g}=0.14 \mathrm{~m} \cdot \mathrm{s}^{-1}\right)$. Apparently, this can explain an insignificant correlation of geostrophic velocity with the depth of the seasonal thermocline upper boundary. Seasonal thermocline location depth and the surface current velocity significantly correlated (the correlation coefficient was -0.74 ).

The change in the depth of the seasonal thermocline upper boundary location, depending on the surface current velocity, is represented in Fig. 3, a. Comparing Fig. 2, $a$ and 3, $a$, we see that the surface current velocity began to increase from December 15, 2012 and reached the maximum on December 19-20 $\left(0.5 \mathrm{~m} \cdot \mathrm{s}^{-1}\right)$, and the seasonal thermocline upper boundary, successively deepening, came to this time to the maximum depth of $45 \mathrm{~m}$. Then, on December 21-23, the surface current velocity decreased, on average, to $0.2 \mathrm{~m} \cdot \mathrm{s}^{-1}$, which caused the rise of seasonal thermocline and CIL to the shallower depths (Fig. 2,a). The subsequent weakening of the surface current velocity to $0.1 \mathrm{~m} \cdot \mathrm{s}^{-1}$ relatively weakly affected the change in the location depth of isotherms limiting the seasonal thermocline.

In the Rim Current southern branch the process of isotherms deformation, depending on the current velocity fluctuations, occurred according to a similar scheme. The only difference was that in this case, on January 26 - February 10, 2014 the average values of geostrophic velocity $\left(V_{g}=0.26 \mathrm{~m} \cdot \mathrm{s}^{-1}\right)$ and the surface current velocity $\left(V=0.22 \mathrm{~m} \cdot \mathrm{s}^{-1}\right)$ were nearly equal. Therefore, due to the fulfillment of the condition of velocity field geostrophic adaptation to the density field (or to the sea level), the correlation between the geostrophic velocity and the seasonal thermocline upper boundary depth was significant at $95 \%$ of confidence level and made up -0.72 .

In Fig. 3, $b$ the change in the seasonal thermocline upper boundary depth depending on the geostrophic velocity is represented. It is clearly seen that, starting from January 28, the geostrophic velocity began to increase, reaching its maximum on January $31-$ February $1\left(0.4 \mathrm{~m} \cdot \mathrm{s}^{-1}\right)$, after which it decreased to $0.15 \mathrm{~m} \cdot \mathrm{s}^{-1}$. Comparing Fig. 3, $b$ and 2, $b$, we see that an increase in geostrophic velocity led to a deepening of seasonal thermocline and CIL, and current velocity weakening led to a rise of the seasonal thermocline and CIL location boundaries to shallower depths. As follows from Fig. 2, $b$, this rise led to a decrease in the UML average temperature limited by the depth of $8.5^{\circ} \mathrm{C}$ isotherm location. 

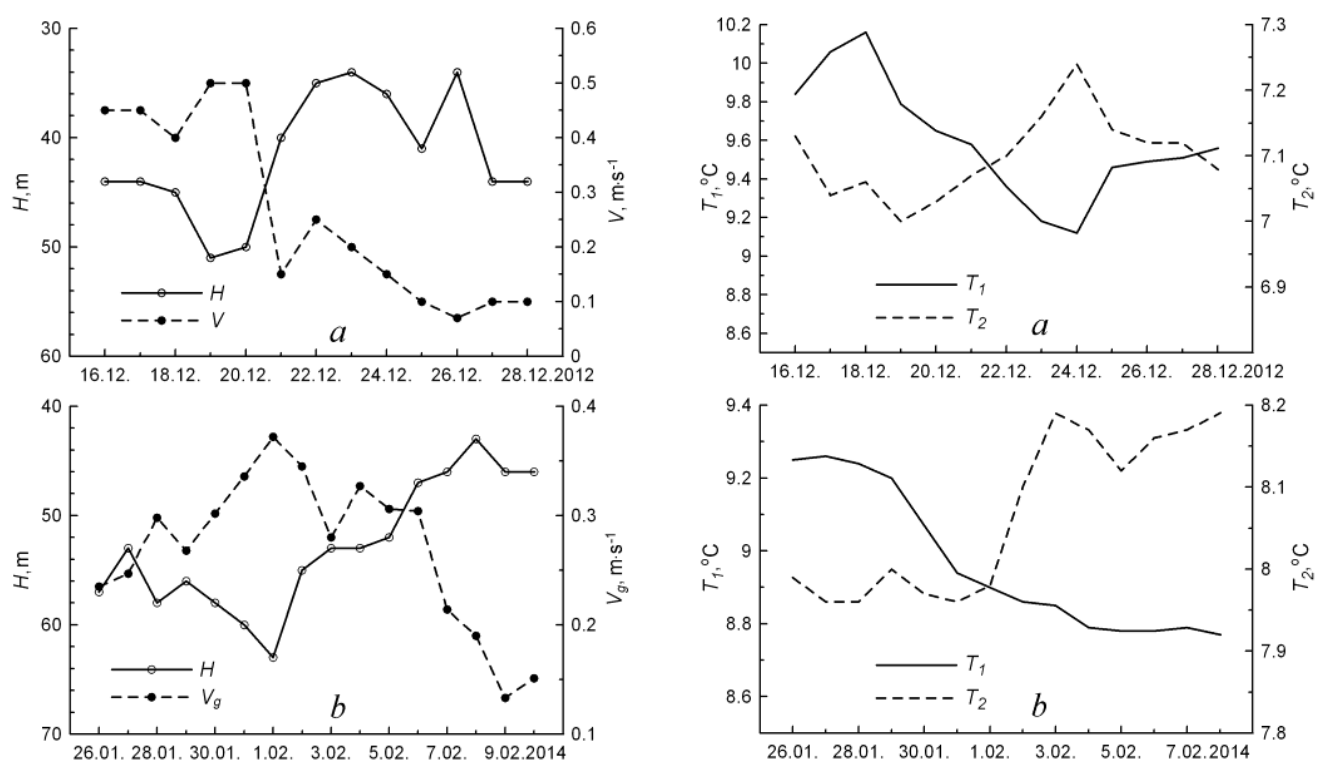

F i g. 3. Position of the seasonal thermocline upper boundary depending on the surface current velocity $V$ and the geostrophic velocity $V_{g}$ in the northern $(a)$ and southern (b) branches of the Rim Current

F i g. 4. Average temperature in the upper mixed layer $T_{1}$ and in the layer below the seasonal thermocline $T_{2}$ in the northern $(a)$ and southern $(b)$ branches of the Rim Current

In the Rim Current northern branch the surface current weakening occurred on December 21-23, 2012 (Fig. 2, a; 3, a) led to a decrease in the UML thickness, which was accompanied by a decrease in its mean temperature (Fig. 2, a). The process of temperature change is illustrated well in Fig. 4, where its mean values in the UML and under the seasonal thermocline for the northern (Fig. 4, a) and southern (Fig. 4,b) Rim Current branches are shown. It can be seen that the sea upper layer mixing due to the increased total heat flux and increased wind velocity was accompanied by the Rim Current velocity increase, which led to a decrease in the UML average temperature, as well as the deepening of seasonal thermocline and CIL. The Rim Current velocity reduction caused the rise of seasonal thermocline and CIL to the shallower depths.

\section{Discussion of the results}

In [15], it was assumed that the Rim Current area has a decisive effect on the ventilation of the sea aerobic layer. Taking into account that in January - February the Rim Current was maximally intensified [9], an analysis of the sea upper layer thermal state reaction to the changing transport rate in the Rim Current in winter was performed. The mixing features in the Rim Current northern and southern branches in the western part of the sea were considered. The obtained results can characterize the mixing processes for the entire sea, since in January - March a single cyclonic circulation of water masses is observed [5]. This cyclonic circulation of the upper layer is determined by the surface wind stress curl, the main contribution to which is made by monsoon and orographic effects [16-18]. 
In general, the wind direction prevailing in the northern part of the sea during the year (northern and northeastern) forms the cyclonic circulation of water [9], and the interannual and synoptic variability of atmospheric circulation in the Black Sea region controls the frequency of wind fluctuation of various direction in the western part of the Black Sea. [2, 9]. Therefore, the considered case of Arctic invasion (January - February 2014) corresponded to the situation when the northeastern wind was observed over the northern part of the sea for several days. Through the drift component, this wind increased the velocity of current, and therefore in the Rim Current southern branch a significant correlation between the wind velocity and the seasonal thermocline location depth $(r=-0.75)$ was noted.

An important circumstance in the mixing process, both during the cold invasion in the rear of the cyclone and during the Arctic invasion, was the fact that the upper layer average temperature decreased in a very short time. Depending on the wind velocity and air - sea temperature difference, the sea surface was cooled, and due to the mechanism of convection and turbulent mixing enhanced by a shift of the current velocity in the upper layer, the UML temperature decreased. The assessments show that in the Rim Current northern branch the average upper layer temperature decreased by $0.1{ }^{\circ} \mathrm{C}$ per day at average daily value $(H+L E)$ equal to approximately $17 \mathrm{~W} \cdot \mathrm{m}^{-2}$ during the period of increased total heat flux from the sea surface and increased wind velocity (December 17-19, 2012). Similar assessments made for the Rim Current southern branch during the period of intense atmospheric forcing (January 29 - February 3, 2014) showed that at average daily value $(H+L E)$ of about $19 \mathrm{~W} \cdot \mathrm{m}^{-2}$, the average temperature of $55 \mathrm{~m}$ upper layer of the sea decreased by $0.1{ }^{\circ} \mathrm{C}$ per day. As can be seen, the values of the total heat flux, which cause a decrease in the UML temperature by $0.1{ }^{\circ} \mathrm{C}$ both in the northern and in the southern branches of the Rim Current, are close.

The geostrophic and surface velocities calculated using satellite altimetry and the operational model NOMADS.NOAA [11] provided a comparison of timevarying Rim Current velocity at the drifter location with the mean temperature fluctuation both in the UML and in the layer located below the seasonal thermocline lower boundary. From Fig. 3, $a, b$, it follows that the location depth of the seasonal thermocline and CIL varies depending on the current velocity. In the Rim Current northern branch (December 2012), at an unstable direction of the surface wind, the location depths of the seasonal thermocline and CIL were regulated by the surface current velocity. Perhaps this is due to the fact that in this case the surface current velocity was about two times higher than the geostrophic one. At an increase in the surface current velocity, the thermocline and CIL deepened; at its weakening, the both layers rose to shallower depths. The same process of changing the location depth of the seasonal thermocline and CIL was also observed in the Rim Current southern branch (January - February 2014). The difference is that in this case the geostrophic velocity and the one of the surface current were equal and the process of changing the location depth of seasonal thermocline and CIL was regulated by the geostrophic velocity. The process of seasonal thermocline and CIL deformation can be represented as an oscillation of the "seasonal thermocline - CIL" system, disturbed from equilibrium by varying atmospheric forcing (which was accompanied by the Rim Current velocity variation). 
With an increase in the total heat flux from the sea surface and wind velocity increase in both northern and southern branches of the Rim Current, the mixing lowers the upper layer mean temperature. With the Rim Current velocity reduction, seasonal thermocline and CIL rise to shallower depths. In this case, as shown in Fig. 2-4, the isotherms characterizing the temperature at the boundaries of the UML and CIL location rise to shallower depths, this leads to a decrease in the UML mean temperature and increase in the mean temperature of the layer below the seasonal thermocline.

In Table 2 the differences in mean temperatures in the UML and in the layer below the seasonal thermocline during the Rim Current velocity increase and reduction are represented. For the northern branch, at the current velocity increase the temperature difference $\Delta T$ was obtained by subtracting the mean temperature for January 18 from the mean temperature for January 20, 2012. For the southern branch $\Delta T=T$ (January 31) $-T$ (January 29, 2014). For the period of the current velocity decrease in the northern branch $\Delta T=T$ (December 24) - T (December 21, 2012); in the southern branch $\Delta T=T$ (February 4, February) - T (February 1, 2014).

Table 2

Change of temperature difference $\Delta T$ in the upper mixed layer (UML) and below the seasonal thermocline during increase and decrease of the Rim Current (RC) velocity

\begin{tabular}{l|cc|cc|c}
\hline \multirow{3}{*}{ Change of RC velocity } & $\begin{array}{c}\Delta T,{ }^{\circ} \mathrm{C} \\
(\mathrm{UML})\end{array}$ & $\begin{array}{c}\Delta T,{ }^{\circ} \mathrm{C} \text { (below } \\
\text { thermocline) }\end{array}$ & $\begin{array}{c}\Delta T,{ }^{\circ} \mathrm{C} \\
(\mathrm{UML})\end{array}$ & $\begin{array}{c}\Delta T,{ }^{\circ} \mathrm{C} \text { (below } \\
\text { thermocline) }\end{array}$ \\
\cline { 2 - 6 } & \multicolumn{3}{|c|}{$\begin{array}{c}\text { Northern branch of the } \\
\text { Rim Current }\end{array}$} & $\begin{array}{r}\text { Southern branch of the Rim } \\
\text { Current }\end{array}$ \\
\hline Increase & -0.51 & -0.03 & -0.26 & -0.04 \\
Decrease & -0.46 & 0.17 & -0.11 & 0.19 \\
\hline
\end{tabular}

Comparing $\Delta T$ values in Table. 2 and in Fig. 2, 4, we can see that both in the Rim Current northern and southern branches the UML temperature decreased not only during the atmospheric forcing intensification (with an increase in the current velocity), but also after its termination. In this case, the main temperature decrease during the current velocity growth occurred in the UML, and under the seasonal thermocline the mixing process was weakened. This corresponds with [15], where the fact that the mixing intensity decreases almost twice, as compared to UML, under a seasonal thermocline is shown. At a current velocity reduction, the temperature in the UML continued to decrease, and in the layer below the seasonal thermocline mean temperature increased.

\section{Conclusions}

The data on the temperature, obtained by drifters, showed that the mechanism of the UML reduced temperatures formation in the Black Sea western part in the winter season in both the northern and southern branches of the Rim Current is approximately the same. $(H+L E)$ value, determining the UML temperature decrease during the day by $0.1^{\circ} \mathrm{C}$ in the northern and southern branches of the Rim 
Current, is $17-19 \mathrm{~W} \cdot \mathrm{m}^{-2}$. But in order to explain the intensity of UML mixing in the Rim Current area, additional studies using anchored measurement systems are required. Such studies are also required in order to eliminate the effect of water masses varying characteristics (in which the drifter moves) on the obtained estimates.

Another feature of the obtained results is the dependence of mixing depth and the sea upper layer temperature on the current velocity. Both in the northern and southern branches the Rim Current intensification leads to the deepening of the seasonal thermocline and the CIL, and the Rim Current weakening leads to their rise to shallower depths. The result of this process is the continuation of the UML temperature decrease at the Rim Current weakening with a simultaneous temperature increase in the layer located below the seasonal thermocline. Thus, the winter atmospheric forcing in the Rim Current area, associated with cold invasion of various intensities, forms a lower temperature of UML. Taking into account the fact that the width of the Rim Current zone is $40-80 \mathrm{~km}$, and the distance at which the drifter displaces from the beginning to the end of the atmospheric forcing in the Rim Current northern branch is $50 \mathrm{~km}$, it can be expected that in the upper sea layer in the Rim Current zone water lenses with lower temperature may form.

\section{REFERENCES}

1. Krivosheya, V.G., Ovchinnikov, I.M. and Skirta, A.Yu., 2002. [Interannual Variability of the Cold Intermediate Layer Renewal in the Black Sea]. In: A. G. Zatsepin, M. V. Flint, eds., 2002. Multidisciplinary Investigations of the Northeast Part of the Black Sea. Moscow: Nauka, pp. 27-39 (in Russian).

2. Titov, V.B., 2003. Effect of Multiannual Variability of Climatic Conditions on the Hydrological Structure and Interannual Renewal of the Cold Intermediate Layer in the Black Sea. Oceanology, 43(2), pp. 164-172.

3. Belokopytov, V.N., 2010. Interannual Variations of the Renewal of Waters of the Cold Intermediate Layer in the Black Sea for the Last Decades. Physical Oceanography, [e-journal] 20(5), pp. 347-355. https://doi.org/10.1007/s11110-011-9090-X

4. Belokopytov, V.N., 2014. [Climatic Variability of the Black Sea Density Structure]. Ukrainian Hydrometeorological Journal, (14), pp. 227-235. Available at:http://uhmj.odeku.edu.ua/klimaticheskaya-izmenchivost-plotnostnoj-strukturychernogo-morya/ [Accessed: 15 December 2018] (in Russian).

5. Ivanov, V.A. and Belokopytov, V.N., 2011. Oceanography of the Black Sea. Sevastopol: MHI, $210 \mathrm{p}$.

6. Bayankina, T.M., Sizov, A.A. and Jurovskij, A.V., 2017. [On the Role of Cold Invasion in the Formation of the Black Sea Winter Surface Temperature Anomaly]. Processes in GeoMedia, (3), pp. 565-572 (in Russian).

7. Kubryakov, A.A. and Stanichny, S.V., 2015. Mesoscale Eddies in the Black Sea from Satellite Altimetry Data. Oceanology, [e-journal] 55(1), pp. 56-67. https://doi.org/10.1134/S0001437015010105

8. Ginzburg, A.I., Zatsepin, A.G., Kostianoy, A.G. and Sheremet, N.A., 2006. Mesoscale Water Dynamics. In: A. G. Kostianoy and A. N. Kosarev, eds., 2006. The Black Sea Environment. The Handbook of Environmental Chemistry, vol. 5Q. Berlin : Springer, pp. 195-215. https://doi.org/10.1007/698_5_062

9. Kubryakov, A.A. and Stanichny, S.V., 2015. Seasonal and Interannual Variability of the Black Sea Eddies and Its Dependence on Characteristics of the Large-Scale Circulation. Deep-Sea Research Part I: Oceanographic Research Papers, [e-journal] 97, pp. 80-91. http://dx.doi.org/10.1016/j.dsr.2014.12.002 
10. Tolstosheev, A.P., Lunev, E.G. and Motyzhev, S.V., 2014. Analiz Rezul'tatov Naturnykh Eksperimentov s Termoprofiliruyushchimi Dreyfuyushchimi Buyami v Chernom More I Drugikh Rayonakh Mirovogo Okeana [Analysis of In-Situ Experiments with TemperatureProfiling Drifters in the Black Sea and Other Areas of the Word Ocean]. Morskoy Gidrofizicheskiy Zhurnal, (5), pp. 9-32 (in Russian).

11. Kubryakov, A.A. and Stanichny, S.V., 2012. Reconstruction of Mean Dynamic Topography of the Black Sea for Altimetry Measurements. Isvestiya, Atmospheric and Ocean Physics, [e-journal] 48(9), pp. 973-979. https://doi.org/10.1134/S0001433812090095

12. Kubryakov, A.A. and Stanichny, S.V., 2013. Estimating the Quality of the Retrieval of the Surface Geostrophic Circulation of the Black Sea by Satellite Altimetry Data Based on Validation with Drifting Buoy Measurements. Isvestiya, Atmospheric and Ocean Physics, [e-journal] 49(9), pp. 930-938. doi:10.1134/S0001433813090089

13. Kubryakov, A.A., Stanichny, S.V., Zatsepin, A.G. and Kremenetskiy, V.V., 2016. LongTerm Variations of the Black Sea Dynamics and Their Impact on the Marine Ecosystem. Journal of Marine Systems, [e-journal] 163, pp. 80-94. https://doi.org/10.1016/j.jmarsys.2016.06.006

14. Anisimov, A.E., Yarovaya, D.A. and Barabanov, V.S., 2015. Reanalysis of Atmospheric Circulation for the Black Sea-Caspian Region. Physical Oceanography, [e-journal] (4), pp. 13-25. doi:10.22449/1573-160X-2015-4-13-25

15. Podymov, O.I., Zatsepin, A.G. and Ostrovsky, A.G., 2017. Vertical Turbulent Exchange in the Black Sea Pycnocline and Its Relation to Water Dynamics. Oceanology, [e-journal] 57(4), pp. 492-504. https://doi.org/10.1134/S0001437017040142

16. Efimov, V.V. and Yurovsky, A.V., 2017. Formation of Vorticity of the Wind Speed Field in the Atmosphere over the Black Sea. Physical Oceanography, [e-journal] (6), pp. 3-11. doi:10.22449/1573-160X-2017-6-3-11

17. Efimov, V.V. and Mikhaylova, N.V., 2017. The Mesoscale Atmospheric Vortex as a Manifestation of the Novorossiysk Bora. Isvestiya, Atmospheric and Ocean Physics, [e-journal] 53(4), pp. 449458. https://doi.org/10.1134/S000143381704003X

18. Kubryakov, A.A., Stanichny, S.V. and Volkov, D.L., 2017. Quantifying the Impact of Basin Dynamics on the Regional Sea Level Rise in the Black Sea. Ocean Science, [e-journal] 13(3), pp. 443-452. https://doi.org/10.5194/os-13-443-2017

About the authors:

Anatoliy A. Sizov - Senior Research Associate, Marine Hydrophysical Institute of RAS (2 Kapitanskaya Str., Sevastopol, 299011, Russian Federation), Ph.D. (Phys.-Math.), ORCID ID: 0000-0001-9055-4768, sizov_anatoliy@mail.ru

Tat'yana M. Bayankina - Research Associate, Marine Hydrophysical Institute of RAS

(2 Kapitanskaya Str., Sevastopol, 299011, Russian Federation), Ph.D. (Geogr.), ResearcherID: G-2535-2019, bayankina_t@mail.ru

Alexander V. Yurovsky - Research Associate, Marine Hydrophysical Institute of RAS (2 Kapitanskaya Str., Sevastopol, 299011, Russian Federation), Ph.D. (Geogr.), ResearcherID: S-1551-2019, a_yurovsky@mail.ru

Contribution of the co-authors:

Anatoliy A. Sizov - formulations of the aims and objectives of the study, analysis of the literature data, discussion and analysis of the research results, discussion and text editing

Tat'yana M. Bayankina - carrying out the calculations, preparing the graphic material for visualizing calculations, discussion of the work results and the text of the article

Alexander V. Yurovsky - processing of the research data, construction of graphic materials for visualization of numerical calculations, discussion of the work results and the text of the article

All the authors have read and approved the final manuscript.

The authors declare that they have no conflict of interest. 